\title{
Suppurative Lymphadenopathy Caused By Bartonella henselae Occurring in Two Siblings Simultaneously
}

\author{
Iki Kardeşte Eş Zamanlı Olarak Ortaya Çıkan Bartonella henselae'nin \\ Neden Olduğu Süpüratif Lenfadenopati
}

\author{
Ümmühan Çay ${ }^{1}$ (ID) \\ ${ }^{1}$ Clinic of Pediatric Infection Diseases, Adana City Hospital, Adana, Turkey
}

Cite this article as: Çay Ü. Suppurative lymphadenopathy caused by Bartonella henselae occurring in two siblings simultaneously. J Pediatr Inf 2020;14(2):e83-e85.

\begin{abstract}
Cat scratch disease is a zoonotic infectious disease caused by Bartonella henselae. Cat scratch disease can be transmitted from an infected cat by a scratch or bite, exposure to cat fleas, contact with impaired skin or mucosa. It is one of the most important causes of infectious lymphadenopathies and frequently occurs in $85-90 \%$ of children as cutaneous and lymph node disorders at the site of organism entry. In $25 \%$ of the affected lymph nodes, skin sensitization, erythema and suppuration with induration develops. In order of frequency, it occurs in axillary, epitrochlear, cervical, supraclavicular and submandibular lymph nodes. In addition to lymphadenopathy, the disease spreads through blood and manifests as bacteremia, fever of unknown cause, conjunctivitis, uveitis, neuroretinitis, encephalopathy, aseptic meningitis, osteolytic lesions, hepatitis, liver and spleen granuloma, endocarditis, erythema nodosum, glomerulonephritis, pneumonia, and thrombocytopenic purpura. Cat scratch disease should be considered in all patients with regional lymphadenopathy and history of cat contact. In the literature, cat scratch disease is rarely reported to be seen simultaneously in more than one member of the family. We reported the cases of two siblings with simultaneous cat scratch disease diagnosis, one with submental and the other with axillary suppurative lymphadenopathy.
\end{abstract}

Keywords: Cat scratch disease, child, sibling, suppurative lymphadenopathy öz

Kedi tırmığı hastalığı Bartonella henselae'nin neden olduğu zoonotik bir enfeksiyon hastalığıdır. Kedi tırmığı hastalığı enfekte bir kediden tırmık veya ısırık, kedi pirelerine maruz kalma, bütünlüğü bozulmuş deriye ya da mukozaya kedi tükürüğünün teması ile bulaşabilir. Enfeksiyöz lenfadenopatilerin en önemli nedenlerinden biri olup sıklıkla çocuklarda \%85-90'ında organizma giriş yerinde kütanöz ve lenf nodu bozukluğu olarak karşımıza çıkmaktadır. Etkilenen lenf nodlarının \%25'inde üzerindeki deri hassas, sıcak eritem ve endürasyonun olduğu süpürasyon gelişir. Sıklık sırasına göre aksiller, epitroklear, servikal, supraklavikular ve submandibular lenf nodlarında görülür. Hastalık kan yoluyla yayılarak bakteremi, nedeni bilinmeyen ateş, konjunktivit, üveit, nöroretinit, ensefalopati, aseptik menenjit, osteolitik lezyon, hepatit, karaciğer ve dalakta granülom, endokardit, eritema nodozum, glomerülonefrit, pnömoni, trombositopenik purpura ile karşımıza çıkmaktadır. Bölgesel lenfadenopati şikayeti olan ve hikayesinde kedi teması olan tüm olgularda kedi tırmığı hastalığı mutlaka düşünülmelidir. Bu yazıda, eş zamanlı biri submental diğeri aksiller süpüratif lenfadenopatisi olan ve kedi tırmığı hastalığı tanısı alan iki kardeş sunulmuştur.

Anahtar Kelimeler: Kedi tırmığı hastalığı, çocuk, kardeş, süpüratif lenfadenopati 


\section{Introduction}

Cat scratch disease (CSD) is a zoonotic disease caused by Bartonella henselae, a gram-negative bacillus. The incidence of CSD is not fully known, and its pathophysiology could not be fully enlightened. Incubation period from cat scratch to primary skin lesion is 7-12 days. Lymphadenopathy occurs 5-50 days after first skin lesions. Cases are particularly seen in autumn and winter (1). CSD can be transmitted especially by infected cats under the age of one through scratching or biting, exposure to cat fleas, and contact of cat saliva to impaired skin or mucosa. Dogs may also be infected and transmit the infection to humans (2). It is most frequently seen in children at the age of 5-9 years (1). CSD is one of the most common reasons of benign, regional lymphadenopathy in children. Lymph node sizes, in most cases, are between $1-5 \mathrm{~cm}$ and usually regress spontaneously within 1-4 months; however, there are cases of lymphadenopathy that continue for 1-3 years (2). Suppuration develops in approximately $25 \%$ of the lymph nodes affected. In order of incidence, it occurs in axillary, epitrochlear, cervical, supraclavicular and submandibular lymph nodes. Fever is not usually seen. Mild systematic symptoms might occur. The disease can cause conjunctivitis involving the conjunctiva and may lead to parinaund oculoglandular syndrome causing ipsilateral pre-auricular lymphadenopathy (1). Spreading through blood, the infection can manifest itself with bacteremia, septic shock, fever of unknown origin, conjunctivitis, uveitis, neuroretinitis, encephalopathy, aseptic meningitis, transvers myelitis, osteolytic lesion, hepatitis, granuloma in the liver and spleen, endocarditis, erythema nodosum, glomerulonephritis, myalgia, arthralgia, arthritis, osteomyelitis, pneumonia, pleural effusion, pulmonary nodules, and thrombocytopenic purpura (2). CSD must be definitely considered in all cases with cat contact and lymphadenopathy complaint. Although lymphadenopathy spontaneously regresses, treatment is recommended to reduce the severity and duration of symptoms and prevent the involvement of vital organs by spreading through blood. CSD rarely occurs simultaneously in more than one child of the family. CSD that occurs simultaneously in siblings has been rarely reported in the literature. CSD must be kept in mind in cases with a history of cat contact, presenting with intrafamilial simultaneous lymphadenopathy.

\section{Case Reports}

\section{Case 1}

A 7 year- 6 month-old male patient was presented with pain, swelling and rash under the chin, ongoing for two weeks. The patient did not have an underlying disease or additional complaint. It was found out from history that the patient lived in a village, came into contact with cats and the patient's sister also had a swelling complaint on her armpit. Physical examination was unremarkable, with the exception of painful, red and fluctuating lymphadenopathy at the submandibular region, $3 \times 3$ $\mathrm{cm}$ in size. Laboratory tests indicated hemoglobin $12.7 \mathrm{~g} / \mathrm{dL}$, leucocyte $7300 / \mathrm{mm}^{3}$, and thrombocyte $291.000 / \mathrm{mm}^{3}$. Polymorphonuclear (PNL) cell domination was seen in peripheral smear examination. Erythrocyte sedimentation rate (ESR) was $9 \mathrm{~mm} /$ hour and C-reactive protein (CRP) was negative. Ultrasonography (USG) showed abscess formation, approximately $35 \times 30$ $\mathrm{mm}$ in size and $18 \mathrm{~mm}$ in thickness. Abscess drainage was performed. Redundant PNL was detected in Giemsa staining but no bacteria grew in gram staining. No growth was seen in pus culture. Chest radiography was normal, tuberculin skin test was anergic, and abdominal USG was normal. IgM levels were found negative in serologic examinations performed for Epstein-Barr virus (EBV), rubella and cytomegalovirus (CMV). Brucella tube agglutination test was negative. No growth occurred in blood cultures. While tularemia agglutination test was negative, anti-toxoplasma IgM and IgG were positive. B. henselae lgG was found positive in $1 / 512$ titer. Ocular examination was normal. Five-day azithromycin treatment was given. During one-month follow up, a $0.5 \times 0.5 \mathrm{~cm}$ lymphadenopathy in the submandibular region was seen. Physical examination was completely normal on the third month follow-up control.

\section{Case 2}

A 5-year-old female patient was presented with pain, swelling and rash on her left armpit ongoing for two weeks. The patient did not have an underlying disease or additional complaints. It was found out from history that the patient lived in a village and her brother had had similar complaints. Physical examination revealed a rigid, fluctuating and painful swelling at the left axillary region, $2 \times 2 \mathrm{~cm}$ in size. Laboratory tests indicated hemoglobin $11.1 \mathrm{~g} / \mathrm{dL}$, leucocyte $8000 / \mathrm{mm}^{3}$, and thrombocyte $333.000 / \mathrm{mm}^{3}$. PNL cell domination was seen in peripheral smear examination. ESR was $9 \mathrm{~mm} /$ hour and CRP was negative. USG showed multiloculated collection (abscess) containing thick-walled septa with an approximate size of 28 x $16 \times 20 \mathrm{~mm}$. The abscess was drained. Redundant PNL was detected in Giemsa staining but no bacteria grew in gram staining. No growth was seen in pus culture. Chest radiography was normal, tuberculin skin test was anergic, and abdominal USG was normal. IgM levels were found negative in serologic examinations performed for EBV, rubella and CMV, but anti-HIV was found positive. HIV confirmation test and HIV-RNA were found negative Brucella tube agglutination test was negative. While tularemia agglutination test was negative, anti-toxoplasma IgM and $\lg G$ were positive. $B$. henselae $\lg G$ was found positive in $1 / 512$ titer. Five-day azithromycin treatment was given. Physical examination was completely normal on the first month follow-up control.

\section{Discussion}

CSD is one of the most important causes of infectious lymphadenopathies. Having a cat as a pet or frequent contact with cats is an important risk factor for CSD. Apart from 
lymphadenopathy, by spreading through blood, the disease can cause bacteremia, septic shock, fever of unknown origin, conjunctivitis, uveitis, neuroretinitis, encephalopathy, aseptic meningitis, transvers myelitis, osteolytic lesion, hepatitis, granuloma in the liver and spleen, endocarditis, erythema nodosum, glomerulonephritis, myalgia, arthralgia, arthritis, osteomyelitis, pneumonia, pleural effusion, pulmonary nodules, and thrombocytopenic purpura (2).

The disease often manifests itself with cutaneous and lymph node lesions at the site of entry of the organism in 85$90 \%$ of the children. CSD must be kept in mind in patients with regional lymphadenopathy, and history of cat scratch must be questioned. It has been reported in a study from our country that history of cat scratch occurring 4-5 weeks prior was found out in a 14-year-old patient presenting with axillary lymphadenopathy, and B. henselae was confirmed by serologic and molecular methods (3). CSD-associated lymphadenopathy is rarely encountered simultaneously in members of the same family with different or similar clinical pictures. Liapi-Adamidou et al. have reported two siblings, one of whom was at the age of 7.5 and presented with complicated long-lasting gastroenteritis, with long-term mesenteric lymphadenitis, hepatosplenic granulomas and osteolytic bone lesions. The other sibling was at the age of 3 and presented with short-lasting, uncomplicated, acute febrile gastroenteritis (4). Gonzalez et al. have reported three siblings diagnosed with CSD, presenting with supraclavicular lymphadenopathy, cervical lymphadenitis and prolonged febrile disease (5). Tan et al. have reported two siblings, aged 5.5 and 4 years, diagnosed with hepatosplenic CSD accompanied by prolonged fever and hypoechoic lesions in the liver and spleen (6). Three members of a family and the veterinarian of the cat has been diagnosed with $B$. henselae-associated lymphadenopathy following contact with the same cat (7). Our cases was presented with axillary and submandibular suppurative lymphadenopathy. CSD rarely occurs simultaneously in members of the same family, and this condition was the first one reported from our country. Cumberworth et al. have reported two siblings with cervical lymphadenitis caused by Mycobacterium avium intracellulare (8). Chakravarti et al. have reported in the literature that they detected cysticercosis-related lymphadenitis during scanning in a sibling of a patient diagnosed with cysticercosis-related cervical lymphadenitis (9). Lindeboom et al. have reported that they confirmed two different agents, $B$. henselae and nontuberculous Mycobacterium in two siblings presenting with cervical lymphadenitis (10).

Both toxoplasma lymphadenopathy and cat scratch lymphadenopathy are associated with exposure to cats. Erythema tenderness and suppuration seen on the skin of patients with CSD are not observed in toxoplasma lymphadenopathy. Biopsy and serology can be helpful in differentiating these two agents. Both microorganisms can be simultaneously seen following exposure to cat. In our first case, anti-Toxoplasma gondii lgG and $\operatorname{lgM}$ were found positive. A decrease in IgM titer but a threefold increase in IgG titer were detected in the serology performed two weeks later. The case was evaluated as acute toxoplasma infection, but upon seeing that the immune system was normal, the patient did not receive treatment for toxoplasma infection. CSD was considered and treatment was regulated accordingly due to suppurative lymph node and positive serology.

In conclusion, CSD must be definitely considered in all patients with regional lymphadenopathy complaints and a history of contact with cat. Notably simultaneous lymphadenopathy among family members, rare agents such as CSD, then Mycobacterium tuberculosis, Mycobacterium avium complex and cysticercosis should be kept in mind in patients presenting with infectious diseases.

Informed Consent: Written consent was received from next-of-kin to the patient.

Peer-review: Externally peer-reviewed.

Author Contributions: Concept - ÜÇ; Design - ÜÇ; Supervision - ÜÇ; Data Collection and/or Processing - ÜÇ; Analysis and/or Interpretation - ÜÇ; Literature Review - ÜÇ; Writing - ÜÇ; Critical Review - ÜÇ.

Conflict of Interest: No conflict of interest was declared by the authors.

Financial Disclosure: The authors declared that this study has received no financial support.

\section{References}

1. Kimberlin DW, Long SS, Brady MT, Jackson MA. Bartonella henselea. In: Red Book 2018: Report of the Committee on Infectious Diseases. American Academy of Pediatrics, 2018:244-7. [CrossRef]

2. Spach $D H$, Sheldon LK. Microbiology, epidemiology, clinical manifestations, and diagnosis of cat scratch disease. http:// www.uptodate.com/contents/Microbiology-epidemiology,clinicalmanifestations,-and-diagnosis-of-cat-scratch-disease Availabla date: 03.11.2019. [CrossRef]

3. Türker K, Çelebi B, Andaç Ş, Bulut P, Yalçın Ş, Dolhan S. A negleted bacteria with a case: Bartonella henselae. Mikrobiyol Bul 2017;51:28692. [CrossRef]

4. Liapi-Adamidou G, Tsolia M, Magiakou AM, Zeis PM, Theodoropoulos $V$, Karpathios T. Cat scratch disease in 2 siblings presenting as acute gastroenteritis. Scand J Infect Dis 2000;32:317-9. [CrossRef]

5. Gonzalez BE, Correa AG, Kaplan SL. Cat-scratch disease occurring in three siblings simultaneously. Pediatr Infect Dis 2003;22:467-8. [CrossRef]

6. Tan TQ, Wagner ML, Kaplan SL. Bartonella henselae hepatosplenic infection occurring simultaneously in two siblings. Clin Infect Dis 1996;22:721-2. [CrossRef]

7. Song AT, Gory M, Roussi J, Salomon J, Cremieux AC, Perronne C, et al. Familial occurrence of cat-scratch disease, with varying clinical expression. Scand J Infect Dis 2007;39:728-30. [CrossRef]

8. Cumberworth VL, Robinson AC. Mycobacterium avium intracellulare cervical lymphadenitis in siblings: a case report and review. J Laryngol Otol 1995;109:70-1. [CrossRef]

9. Chakravart A, Bhargava R, Agarwal S. Unusual cause of neck swelling in two siblings. Int J Pediatr Otorhinolaryngol Extra 2014;9:36-8. [CrossRef]

10. Lindeboom JA, Schreuder WH. Similar presentation of cervical lymphadenitis of different etiology in two siblings. Oral Surg Oral Med Oral Pathol Oral Radiol 2016;122:51-4. [CrossRef] 